\title{
A versenyek szerepe az algoritmikus gondolkodás fejlesztésében, az Országos Méh-Ész Logikai Verseny bemutatása
}

\author{
Kiss András \\ Egri Balassi Bálint Általános Iskola
}

\begin{abstract}
Absztrakt
Az algoritmikus gondolkodás fejlesztése különböző színtereken és különböző eszközök segítségével valósulhat meg, az egyik lehetséges forma a témához kapcsolódó versenyeken való részvétel. Ezek az alkalmak lehetőséget biztosítanak a résztvevők tudásának összemérésére, önismeretük fejlesztésére és nem utolsó sorban élményt és kihívást jelentenek a számukra. Tanulmányomban egy, a 2017/2018-as tanévben útjára indult kezdeményezést, az Országos Méh-Ész Logikai Versenyt és az ehhez kapcsolódó kiegészítő tevékenységeket mutatom be. Megismerhetjük a verseny létrejöttének előzményeit, bepillantást nyerhetünk a szervezés és megvalósítás folyamatába, nehézségeibe. Bemutatásra kerülnek a megrendezés két éve során elért sikerek a résztvevők számának és a versennyel kapcsolatos visszajelzések tükrében. A megvalósítás során szerzett tapasztalatok közül kiemelt figyelmet szentelek az egyik legnagyobb veszélyforrásnak, a nagymértékủ lemorzsolódásnak és az ennek elkerülése érdekében tett lépéseknek.
\end{abstract}

Kulcsszavak: verseny, motiváció, Bee-Bot, játékosítás, digitális történetmesélés

\section{Bevezető}

$\mathrm{Az}$ algoritmikus gondolkodás fontos szerepet játszik a mindennapi életünkben, segítségével megfelelhetünk a korunk információs társadalma által támasztott újabb kihívásoknak. Ehhez rendelkeznünk kell az információk gyors és hatékony elérését biztosító digitális kompetenciákkal, amelyek megalapozzák az élethosszig tartó tanulás folyamatát. Egy jól bevált algoritmus felhasználása által felmerülő problémák, kihívások megoldása közben sok időt és energiát megtakaríthatunk (Szántó, 2002). Ebben, az új helyzethez igazítva biztos segítséget nyújt az egyszerủbb problémák megoldása során szerzett jártasság. Az algoritmikus gondolkodás képességének megalapozására, fejlesztésére az óvodai nevelés és az általános iskolai oktatás-nevelés során is kiemelt figyelmet kell szentelnünk, hiszen meghatározó szerepet tölt be a digitális állampolgárrá válás folyamatában. Fontos, hogy a problémák 
megoldása ne a saját elgondolásaink megvalósításáról szóljon, adjunk teret a tanulók elképzeléseinek, emellett tudatosítsuk bennük, hogy akár több helyes út is létezhet, és ezek közül különböző szempontok figyelembevételével az egyik hatékonyabb lehet, mint a másik (Szántó, 2002).

\section{Az algoritmikus gondolkodás fejlesztése IKT-eszközökkel}

Az algoritmikus gondolkodás fejlesztése különböző színtereken és különböző eszközök segítségével valósulhat meg. Az IKT-eszközök szerepe, mint az élet többi területén, itt is egyre jelentősebb, ma már ezek igen széles palettájával találkozhatunk. A legtöbb esetben online fórumok, szakmai közösségek alakulnak ki körülöttük, ahol a használatukat, bevezetésüket megkönnyítő segédanyagokat, könnyen adaptálható jó gyakorlatokat találhatunk. A technológia gyerekekre gyakorolt motiváló hatása is jelentős, a felhasználható virtuális illetve kézzel fogható eszközök sikerélményhez juttatják őket, az azonnali visszacsatolás által pedig könnyedén tesztelhetik algoritmusaik müködését és elvégezhetik a szükséges módosításokat. A fiatalabb korosztály körében végzett fejlesztés során különösen jól használható eszköznek bizonyulnak a padlórobotok, amelyek segítségével az algoritmikus gondolkodás alapjainak elsajátításán túl a problémamegoldás, a kreativitás, a téri tájékozódás, az együttmüködés és a szociális kompetenciák is sikerrel fejleszthetők. Alkalmazásukkal a tanulók észrevétlenül, játékos tevékenységek végrehajtása során aktívan bevonódnak az ismeretátadás folyamatába, miközben a pedagógus facilitátorként a háttérből irányítja a tevékenységsorozatot. A padlórobotok, a NAT céljaival összhangban, bármelyik mủveltségi területhez kapcsolódóan sikerrel alkalmazhatók tanórai és tanórán kívüli keretek között is. A hagyományos, frontális oktatásszervezési móddal és munkaformákkal szakítva alkalmazásuk lehetőséget biztosít a diákok közötti együttműködésre, a nagyfokú differenciálásra, segítségükkel, saját algoritmusaik megfigyelése és korrekciója által fejlődik az önértékelésük, az oktatóknak pedig lehetősége adódik a formatív értékelés széleskörű alkalmazására. Felhasználásuk egyik nagy előnye, hogy sem a tanulók, sem a pedagógusok részéről nem igényelnek különösebb informatikai ismereteket, kezelésük könnyen elsajátítható. Alkalmazásuk során a fokozatosság elvének betartásával játszva juttathatjuk el a gyerekeket az egyszerübb algoritmusok megvalósításától az összetett feladatok önálló megoldásáig. Ezen eszközök széles választékából elsőként a Bee-Bot padlórobotok kipróbálására nyílt lehetőségem az általam megvalósított „A kazamaták kincsei - kódoló kalandok a Balassiban” címü projekt során. Ennek keretében egy CoderDojo stílusú foglalkozássorozatot indítottam útjára, ahol a résztvevők változatos tevékenységek és munkaformák során ismerkedtek meg az algoritmizálás és a programozás alapjaival. A közös munka során felhasználásra kerültek a játékosítás és a digitális történetmesélés módszerének egyes elemei is, melyek segítségével a projekt teljes időtartama alatt fenntartható volt a résztvevők motivációja. A CodeCombat 
nevű online alkalmazás pályáit alapul véve a diákok elkészíthették saját kazamatáikat is, amelyeket a Bee-Bot padlórobotok segítségével bejárhattak, így a játékbéli virtuális világot valóságossá tehették. A projekt részletes leírása megtalálható a Tempus Közalapítvány Digitális Módszertárában (https:// tka.hu/tudastar/dm/470/kodolo-kalandok-a-kaza- matak-kincsei).

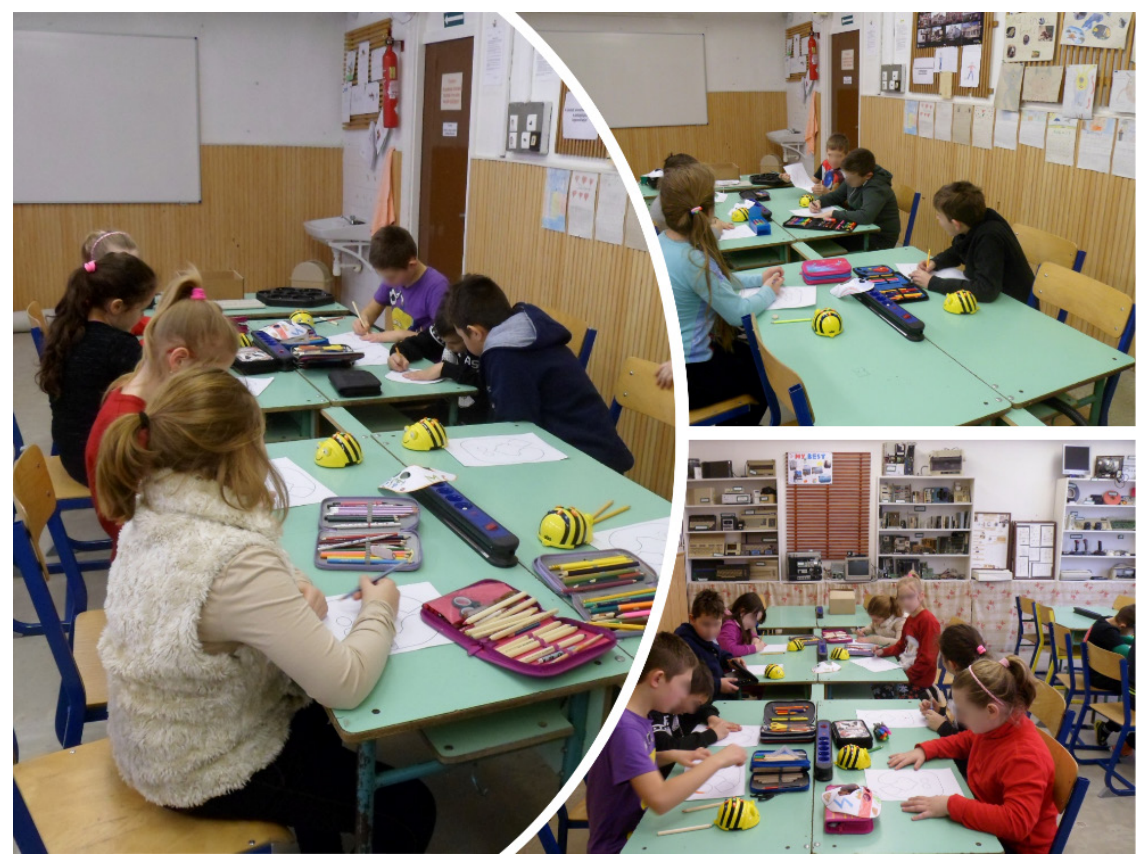

1. ábra

A „kalandorok” munka közben

(Forrás: saját fotók).

A Bee-Bot padlórobotok egyből elnyerték a diákok tetszését, formájuk, használhatóságuk és alkalmazásuk újszerüsége által. A gyakorlati felhasználás közben számomra is nyilvánvalóvá vált, hogy egy, a mindennapi nevelö-oktató munka során sikeresen alkalmazható eszközről van szó, így a későbbiekben változatos formákban igyekeztem kiaknázni a bennük rejlő lehetőségeket. Az általam megszervezett Országos Méhész Logikai Versenynek is kiváló alapjául szolgáltak.

\section{Versenyek szerepe az algoritmikus gondolkodás fejlesztésében}

Az algoritmikus gondolkodás fejlesztésének egyik lehetséges színtere a témához kapcsolódó versenyeken való részvétel. Hazánkban jelentős hagyo- 
mánya van a versenyeztetésnek (például Fülöp, Berkics \& Pinczés-Pressing, 2015), de az adott témában, főleg a legkisebbek, az óvodások számára kevés lehetőség adódik erre. Ennek egyik lehetséges oka, hogy ebben a korban még kialakulóban van a szabálytudat és a kudarctűrő-képesség, így egy „komoly” versenyen való részvétel nem biztos, hogy pozitív hatással lenne a gyermekek fejlődésére, azonban egy, az életkori sajátosságokat szem előtt tartó, játékos, sikerélmény-orientált kezdeményezés hozzájárulhat ezen képességek fejlődéséhez is. A versenyek lehetőséget biztosítanak a résztvevők számára tudásuk összemérésére, önismeretük fejlesztésére és nem utolsó sorban élményt, kihívást jelent számukra (Fülöp, 2001). Véleményem szerint a megvalósítás kulcsa a minél több formában megvalósuló pozitív visszacsatolásban, a sikerélmény nyújtásában rejlik, kiváltképpen az adott korosztály vonatkozásában. Csakúgy, mint bármely pedagógiai tevékenység során, itt is fontos a megfelelő tervezés, az alapos előkészítés, hiszen a rossz tapasztalatok, a kudarcélmény akár negatív hatással is járhat, elveheti a gyerekek kedvét a további hasonló jellegü tevékenységektől. A fiatalabb korosztály esetén különösen fontos szerepet töltenek be a felkészítő pedagógusok és a szülők: egyrészt a versenylehetőségek megtalálásában, másrészt a részvétel biztosításával, illetve a motiváció fenntartása által.

\section{Az Országos Méh-Ész Logikai Verseny}

A 2017/2018-as tanévben egy, az intézményünk beiskolázását támogató programsorozatot terveztem és valósítottam meg. Ennek első lépéseként, az érdeklődés felkeltése céljából a környező óvodákban robotbemutatókat szerveztem, ahol játékos keretek között nyújtottam betekintést a Bee-Bot padlórobotok felhasználási lehetőségeibe, ennek során kulcsszerepet kapott a humor, amely hozzájárult a megfelelően pozitív légkör kialakításához. Ezután iskolánkban egy nyolcalkalmas délutáni foglalkozássorozaton vehettek részt az érdeklődő óvodások, ahol különféle tevékenységi formákon keresztül ismerkedhettek meg többek között a Bee-Bot padlórobotok használatával. A megvalósítás során a hagyományos manuális tevékenységek és a modern IKT-eszközök felhasználása egyaránt jelen volt. A résztvevő gyerekek bevonását elősegítendő pedig a digitális történetmesélés módszerének egyes elemeit is felhasználtuk. Az életkori sajátosságaiknak megfelelően, a fokozatosság elvét figyelembe véve előbb egy jól ismert mesét (A kiskakas gyémánt félkrajcárja) dolgoztunk fel, majd irányított formában, előre elkészített szereplőket ábrázoló kártyák segítségével, és végül teljesen önállóan alkothatták meg saját történeteiket. A foglalkozások középpontjában mindvégig a pozitív megerősítés, a jutalmazás, az önbizalom növelése, a témához és az iskolai oktatáshoz füződő pozitív attitűd kialakítása állt. A tevékenységekbe a szülők részvétele is biztosított volt, többen közülük aktívan be is kapcsolódtak a közös munkába. A foglalkozássorozatot egy „vizsgával” zártuk, ahol mindenki sikeresen elnyerte a „hivatásos Bee-Bot röptető” címet. A projekt 
részletes leírása megtalálható a Tempus Közalapítvány Digitális Módszertárában (https://tka.hu/tudastar/dm/472/bee-bot-szakkor-ovodasoknak).

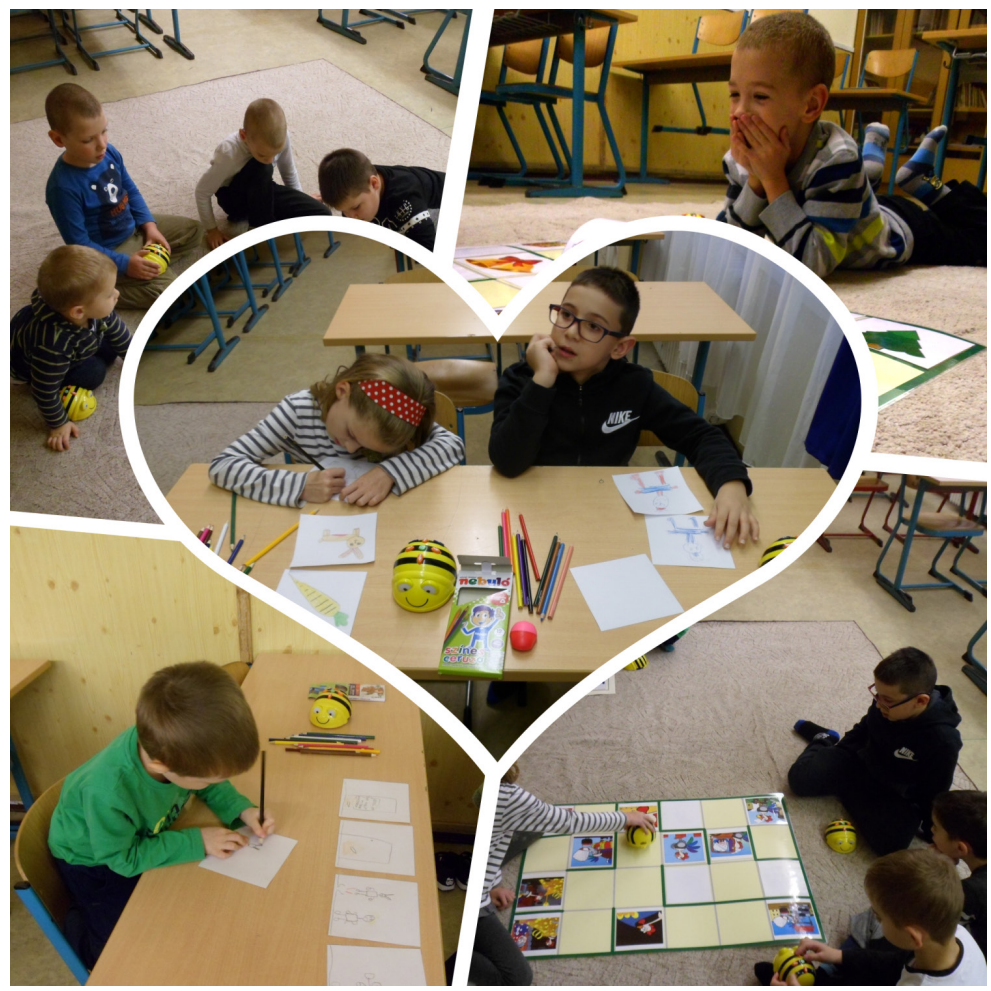

2. ábra

Bee-Bot szakkör óvodásoknak

(Forrás: sajátfotók).

A kapcsolat fenntartása és erősítése érdekében a szakkör résztvevői számára egy levelezős versenyt terveztem, amelyet hagyományos „snail mail” formában képzeltem el, de végül a beküldés és a javítás megkönnyítésének érdekében teljesen online formában valósítottam meg. Ennek következtében a verseny kezdeti célcsoportja és hatóköre is jelentősen megváltozott az előkészítő tevékenység során, az óvodás korosztályon túl az általános iskola alsó tagozatos diákjai számára is lehetőséget biztosítottam a részvételre, illetve a városi meghirdetés is országosra módosult. Nagy örömet és egyben meglepetést is okozott az első fordulóra beérkezett több, mint 600 megoldás. Ez a szervezés és lebonyolítás mellett a jutalmazás terén is komoly fejtörést okozott, de céljaim megvalósításához sikerült elkötelezett támogatókat ta- 
lálnom. A verseny az első évében összesen 116 intézményből 775 gyermeket ért el, ez a következő évben megkétszereződött, 206 intézményből összesen 1546 gyermek vett részt a megmérettetésen.

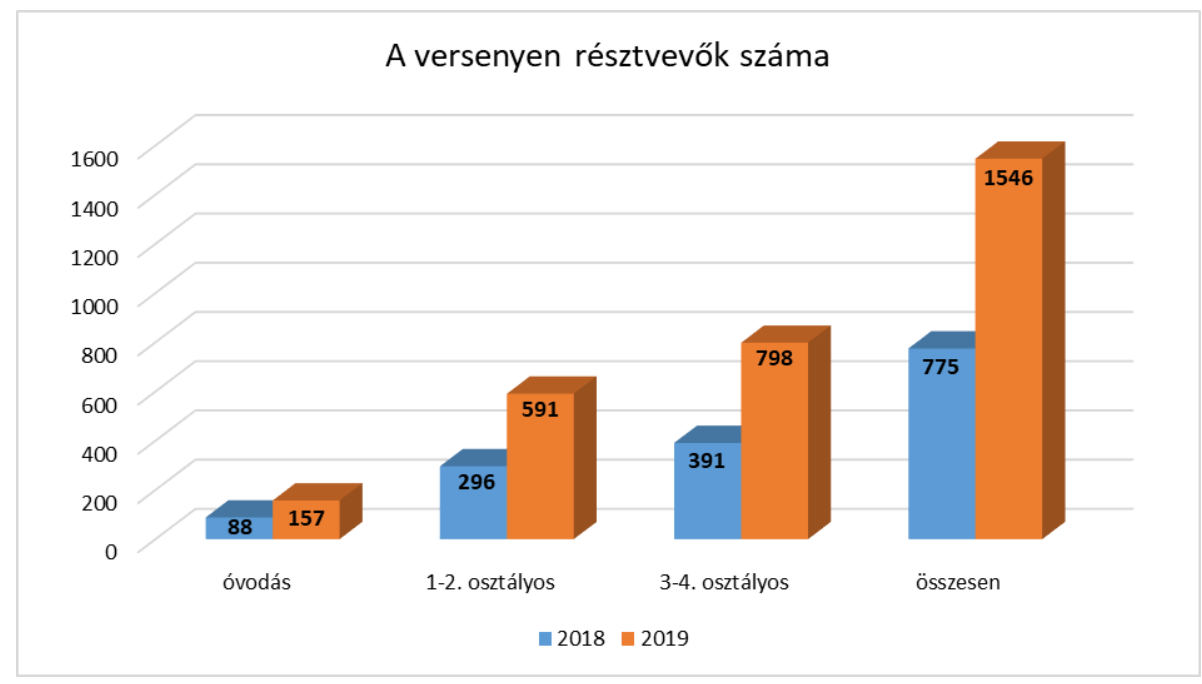

3. ábra

A résztvevők száma és korcsoportonkénti eloszlása

(Forrás: saját szerkesztés).

Az Országos Méh-Ész Logikai Verseny (https://beebotverseny.hu/) megvalósítása során a legfontosabb célom, a résztvevők és felkészítők érdeklődésének felkeltése volt, céljaim szerint ezáltal megalapozva egy lehetséges későbbi tevékenységsorozatot. Ezen túlmenően a családok bevonódása is megfigyelhető, mivel sok esetben a feladatok megoldása otthoni közös programmá vált. A megvalósítás során a tehetségek felismerésén és azonosításán túl a versenyhelyzet gyakorlása, a siker- és a kudarcélmény megfelelő kezelésének kialakítása, a versenyzők önismeretének, önbizalmának fejlesztése is célom volt. A megszerezhető jutalom által biztosított megerősítésnek, mint külső motivációs erőnek is fontos szerep jutott, a legeredményesebb versenyzők a támogatók által felajánlott nyereményekben részesültek - bár az ehhez szükséges források megtalálása sokszor nem volt egyszerü feladat. A résztvevők mellett a felkészítők elérése is központi szerepet töltött be, mivel az eszközök lehetőségeinek bemutatása hozzájárulhat a pedagógusok - és áttételesen az intézmények digitális átállásához is. A diákok lehető legszélesebb körének elérése érdekében a legkisebbek számára is könnyen használható, külön regisztráció nélkül elérhető beküldési rendszert dolgoztam ki, illetve a feladatokat nyomtatható formában is elérhetővé tettem, lehetővé téve ezáltal azt, hogy akár a felkészítők 
is rögzíthessék a megoldásokat. Mivel sokan nem rendelkeznek tapasztalattal a Bee-Bot padlórobotok használata terén, így a verseny honlapján különböző segédanyagok (oktatóvideók, mintafeladatok) ismertetik meg azok müködését a résztvevőkkel, bemutatják számukra a verseny feladatait, azok logikáját. Ezeken túl az érdekes, elgondolkodtató feladatok és a verseny ingyenessége is hozzájárul a diákok minél szélesebb körének eléréséhez. Mind az ingyenesség, mind a későbbiekben bemutatásra kerülő, a versenyhez kapcsolódó Vándor Bot program egyik legfontosabb célja a diákok közötti digitális szakadék csökkentése, azok számára is lehetővé téve a versenyen való részvételt, a Bee-Bot padlórobotok gyakorlatban történő kipróbálását, akik esetleg anyagi okok miatt nem tudnának élni ezzel a lehetőséggel.

\section{A résztvevők lemorzsolódásának csökkentése}

Az elmúlt években aktív résztvevője voltam több MOOC-kurzusnak is, illetve azok tervezésének alapjaival is megismerkedtem egy ilyen típusú továbbképzés alkalmávalvel. Ezen tapasztalataimat is felhasználtam a verseny megvalósítása során, mivel több hasonlóságot is felfedeztem a két tevékenységi forma között. Az egyik legfontosabb kapcsolat, hasonlóság a nagymértékủ lemorzsolódás veszélye, amely elkerülésére már a kezdetektől különös figyelmet fordítottam. A lemorzsolódást minimalizálandó céllal a játékosítás és a digitális történetmesélés módszerének egyes elemeit használtam fel, illetve a játékosítás alapvető eszközét, a PBL-t, vagyis a Pontok (Points), a Jelvények (Badges) és a Ranglisták (Leaderboards) rendszerét hívtam segítségül. Az egyes fordulók során szerezhető pontok és a ranglista tekintetében a második évben változtatásokat hajtottam végre, mivel az előző év tapasztalatai azt mutatták, hogy egy-egy rosszabb eredmény után gyakran nem érkezett több megoldás az adott versenyzőtől, így az új rendszerben a pontszámok csak a verseny végeztével váltak elérhetővé. A résztvevők az egyes fordulókon elért teljesítményükről két kategóriába sorolva kaptak visszajelzést egy mosolygós és egy félig mosolygó Bee-Bot formájában, társítva a „Nagyon ügyes! A megoldásod tökéletes, vagy csak kis hibád van”, illetve az „Ügyes vagy! De valamit kicsit elnéztél” üzenettel. Emellett a résztvevők a beküldött megoldásaikat a verseny felületén megtekinthették, egy „virtuális” Bee-Bot bejárta az általuk megadott útvonalakat, így folyamatosan ellenőrizhették a feladat megoldásához készített algoritmusaik helyességét és elég pontos következtetéseket vonhattak le az elért pontszámmal kapcsolatban is. Az eredmények pontos ismeretének hiányában fennálló kis bizonytalanság a verseny végéig elkísérte, motiválta a gyerekeket. Ezeken túl a versenyhez füződő kapcsolat erősítése és fenntartása érdekében a különböző tevékenységekkel megszerezhető jelvények rendszerét dolgoztam ki (4. ábra), amelyek részletesen megtekinthetők a verseny honlapján (https:// beebotverseny.hu/jelveny.php). Ezek igen pozitív fogadtatásra találtak a résztvevők körében, sokszor a feladat megoldásának egy nehezebb módját választották, csak azért, hogy az adott jelvényt begyüjthessék. 

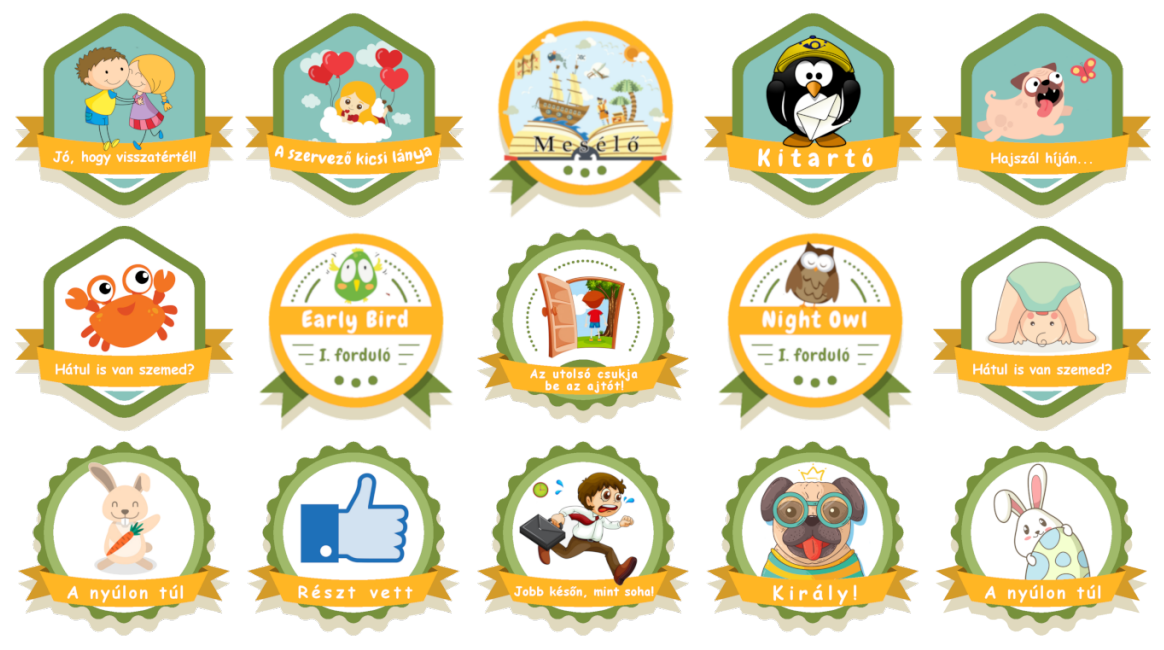

4. ábra

Néhány, a verseny során megszerezhetö jelvény

(A jelvények szerkesztése során fel-

használt képi elemek forrása: https://www.freepik.com/).

A verseny élményét, emellett az egész verseny kerettörténetbe foglalása, az egyes fordulók feladataiként megfogalmazott küldetések teljesítése, illetve két mellékküldetés is fokozta. A verseny végeztével mindenkinek lehetősége adódott a történet egyéni befejezésére, egy utasítássorozat és az ahhoz tartozó narratíva beküldésével megírhatták a cselekmény utolsó fejezetét. A beküldők ezzel a tevékenységgel is jelvényt szerezhettek, illetve a legjobb befejezés írója oklevélben és tárgyjutalomban részesült. Ezen elemek megítélését, fontosságát, a verseny végeztével kitöltött résztvevői és felkészítői elégedettségmérő kérdőívek során vizsgáltam meg, melynek eredményét az 5. ábra mutatja be. 
A versenyek szerepe az algoritmikus gondolkodás fejlesztésében, az Országos Méh-Ész Logikai Verseny bemutatása

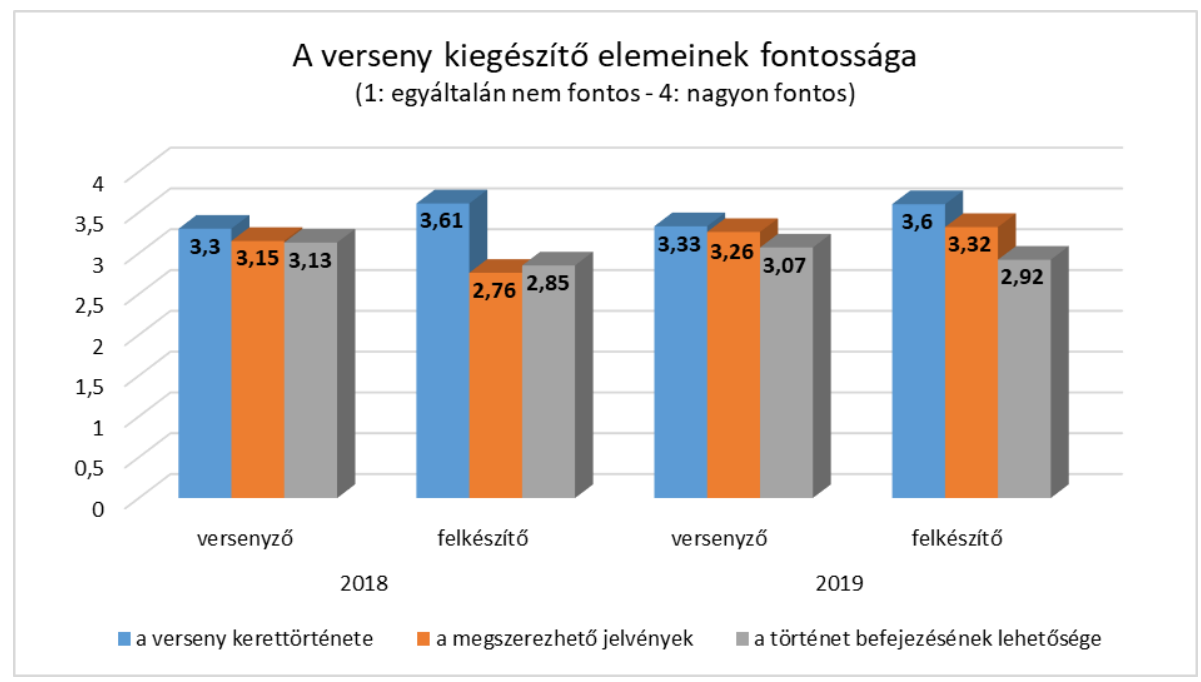

5. ábra

A verseny kiegészitö elemeinek fontossága a visszajelzések alapján

(Forrás: saját szerkesztés).

\section{A verseny feladatai}

A résztvevőket az egyes fordulók feladatainak elkészítésekor a fokozatosság elvét figyelembe véve folyamatosan nehezedő kihívások elé állítottam. Mivel a verseny legfőbb célja a motiváció felkeltése, a minél több csatornán történő pozitív megerősítés biztosítása, így a feladványok nehézségi szintjének meghatározása során egy közepes szintet próbáltam tartani, ami még nem túl nehéz, de mégis kihívást rejt magában. A 6. ábra bemutatja, hogy az elégedettségmérés eredményei alapján mennyire találták nehéznek az egyes feladatokat a felkészítők, ennek eredménye jól tükrözi az egyes fordulók fokozódó nehézségét, illetve az utolsó küldetés levezető jellegét. Emellett az első év visszajelzései alapján a második évben a verseny egészének nehézségi szintjét megemeltem. 


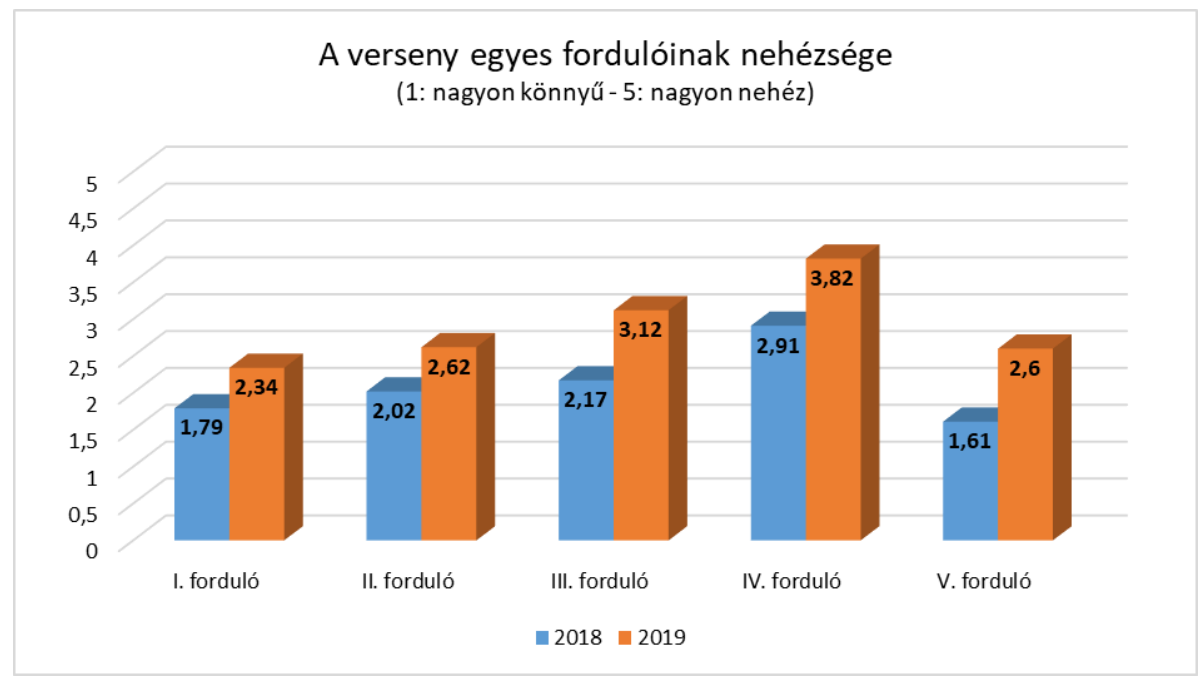

6. ábra

Az egyes fordulók nehézségi szintje a felkészitók visszajelzése alapján (Forrás: saját szerkesztés).

$A$ feladatok tervezése során igyekeztem az algoritmikus gondolkodás különböző szintjeit bevonni és ezáltal aktivizálni, fejleszteni a résztvevők megfelelő kompetenciáit. A verseny leírása hatékonysági szempontból a küldetések minél kevesebb utasítással történő elvégzését tűzte ki célul, illetve bizonyos jelvények megszerzése érdekében a résztvevőknek a tervezés és a megoldás során más szempontokat is figyelembe kellett venniük. Mindemellett fontos volt, hogy a feladványok (a mintafeladatot is beleértve) kapcsolódjanak a kerettörténethez, annak egy-egy eseményét meséljék el. Mivel a versenyt teljesen egyedül, önerőből valósítottam meg, gyakorlatias szempontokat is figyelembe kellett vennem, ezért olyan feladatokat állítottam össze, amelyek az általam készített program segítségével könnyen kiértékelhetők, ellenkező esetben a több ezer beérkezett megoldás kijavítása, pontozása megoldhatatlan lett volna számomra.

\section{Vándor-Bot program}

A verseny az eredményhirdetéssel még nem zárult le teljesen, az egyik támogatásnak köszönhetően egy mini csámborgást, a Vándor-Bot programot is beindíthattam. Ennek keretében a versenyen részt vevő intézmények a gyakorlatban is megismerkedhetnek egy Bee-Bot padlórobot használatával. A kipróbálást követően, a visszajelzések alapján több esetben saját eszközt is beszereztek. A programban részt vevő intézmények földrajzi elhelyezkedését a 7. ábra mutatja. 


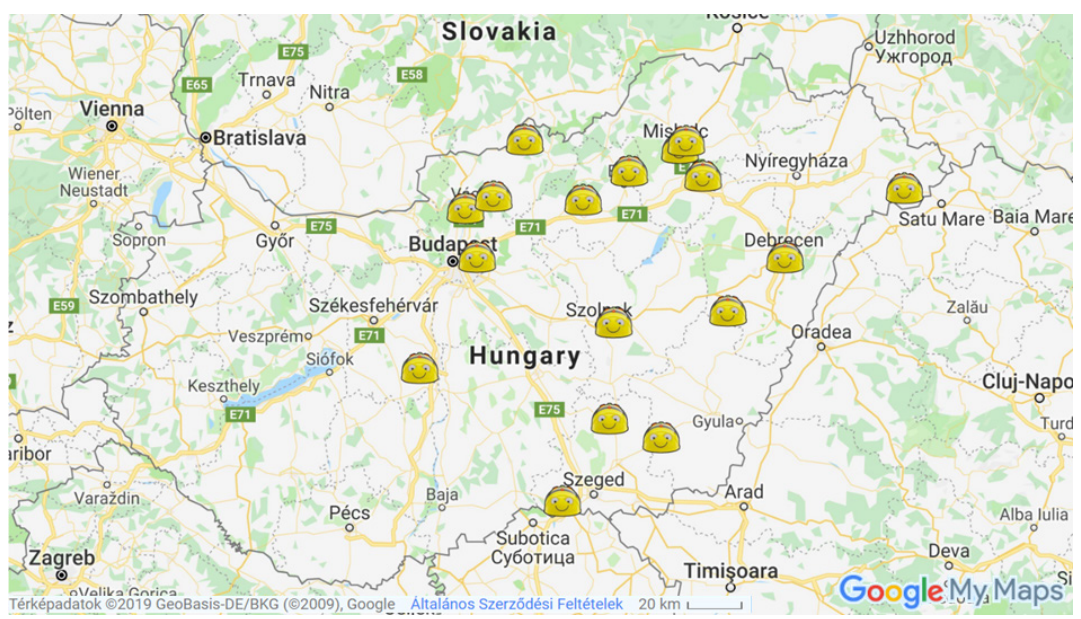

7. ábra

A Vándor-Bot programban résztvevő intézmények elhelyezkedése

(Forrás: Google Térkép).

\section{Összegzés}

A verseny sikerességét jól mutatja, hogy a második évében szép számmal voltak visszatérő versenyzők is, és a két év alatt mintegy 2000 gyermeket ért el a kezdeményezésem, jelenleg pedig 1957 résztvevővel zajlik a megvalósítás harmadik éve. Fő célom az érdeklődés, a motiváció felkeltése, ennek elérése érdekében pedig a lehetőségekhez mérten minél több csatornán próbálok pozitív visszajelzést adni a résztvevők munkájával kapcsolatban. Ezt a célt szolgálják a verseny folyamatába bevont, a játékosítás és a digitális történetmesélés módszeréből átvett elemek és a legeredményesebb résztvevők jutalmazása is. A verseny két éve alatt összesen 70 gyermek részesült tárgyjutalomban, emellett a legeredményesebb és a legaktívabb iskola, illetve a verseny történetének legötletesebb befejezése is díjazásra került. Mivel az anyagi lehetőségeim nem tették lehetővé, hogy mindenkit megjutalmazzak, így köztes megoldásként valamennyi résztvevő és a felkészítőik is a verseny honlapjáról emléklapot, a kiemelkedő teljesítményt nyújtók pedig oklevelet tölthetnek le. A pozitív visszacsatolás igen fontos formája ezeken túl, hogy a résztvevők által elért eredmények, a megszerzett jelvények mások számára is megtekinthetők, így a környezetük is értesülhet a teljesítményükről.

A verseny eddigi két alkalommal történő megvalósítása teljesítette az előzetesen kitűzött célokat, sikerült a téma iránt felkelteni a résztvevők és a felkészítők érdeklődését. Egy, a számukra elkészített elégedettségi kérdő- 
ív segítségével adhattak visszajelzést a versennyel kapcsolatban, ezt az első évben 66 résztvevő és 34 felkészítő, idén pedig 150 résztvevő és 65 felkészítő töltötte ki, ezek kiértékelése is alátámasztja a sikeres megvalósítást és hozzájárul a célközönség igényeinek a jövőben történő minél szélesebb körű figyelembevételéhez. (8. ábra)

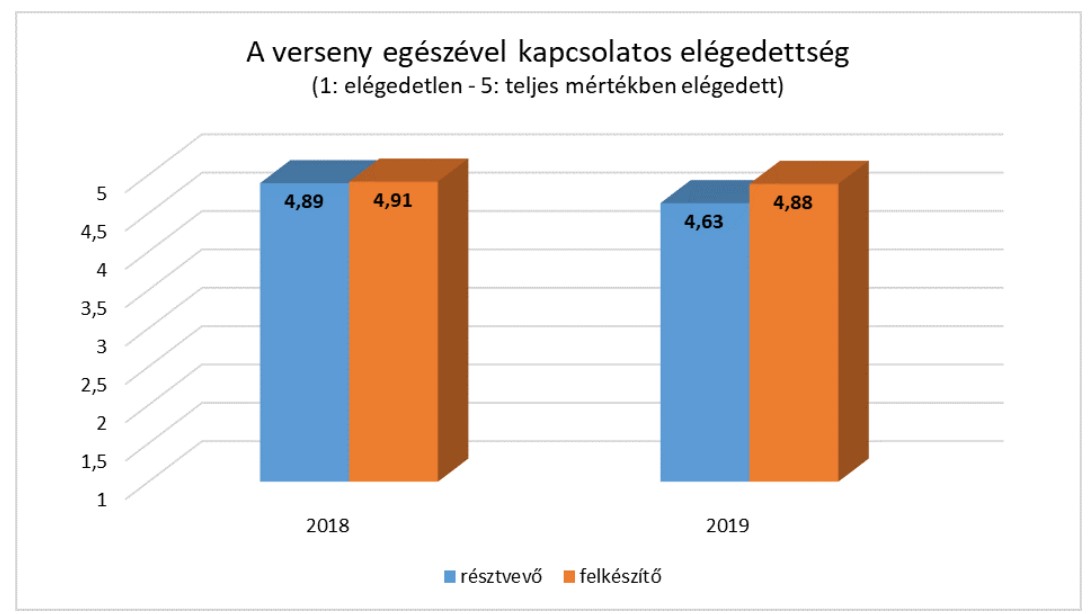

8. ábra

A verseny egészével kapcsolatos elégedettség

(Forrás: saját szerkesztés).

Az Országos Méh-Ész Logikai Verseny megvalósításával kapcsolatban a legfontosabb tanulság számomra, hogy egy átlagos pedagógus egyszerü kezdeményezéséből is születhet valami nagyszabású, sikeres dolog. Tény azonban, hogy ehhez rengeteg munka és kitartás szükséges.

A legértékesebb visszajelzést az egyik résztvevőtől kaptam: „Sajnos jövőre 5. osztályos leszek, és nem indulhatok a versenyen. ()

\section{Irodalom}

Szántó, S. (2002). Az algoritmikus gondolkodás fejlesztése általános iskolában. Új Pedagógiai Szemle, 52(5), 84-91.

Fülöp, M., Berkics, M., \& Pinczés-Pressing, Zs. (2015). A verseny szerepe a versenyzők életében és az eredményes versenyzés lehetséges pszichés összetevői. Matehetsz (Géniusz mühely). http://tehetseg.hu/sites/default/files/geniusz_muhely/nwp18. $\operatorname{pdf}(2020.05 .12$.)

Fülöp, M. (2001). A versengés szerepe. Új Pedagógiai Szemle, 51(11), 3-17. 


\section{Kiss, A.}

\section{Digital land-taking - in the world of infants}

Development of algorithmic thinking can be made on several platforms with several tools. One of them is the competition. The paper presents an initiative started in the year 2017/2018 called Országos Méh-Ész Logikai Verseny and gives a detailed description of its preparation and execution.

Keywords: competition, motivation, Bee-Bot, gamification, digital storytelling

Kiss András: https://orcid.org/0000-0001-5788-8782 